\title{
Modification of growth medium of mixed-culture species of microalgae isolated from southern java coastal region
}

\author{
Hanifrahmawan Sudibyo ${ }^{1}$, Yuni Purwanti $^{2}$, Yano Surya Pradana $^{1}$, Thoriq Teja Samudra $^{2}$, Arief Budiman ${ }^{1}$, Eko Agus \\ Suyono $^{2, *}$ \\ ${ }^{1}$ Chemical Engineering Department., Universitas Gadjah Mada, Jalan Grafika No. 2, Yogyakarta, Indonesia, 55281 \\ ${ }^{2}$ Faculty of Biology, Universitas Gadjah Mada, Jalan Teknika Selatan, Yogyakarta, Indonesia
}

\begin{abstract}
Globally, there is growing interest in microalgae as production organisms. Microalgae contain lipids (oil), proteins and carbohydrates (sugars), and, especially marine algae have been used as food and feed for centuries. Recently, production cost reduction related to the supply of growth nutrients is necessary to make it profitable. Therefore, utilization of molasses, a byproduct of sugar production, as the natural carbon, macronutrients, and micronutrients sources can be helpful. The analysis showed that the content of sucrose, glucose, fructose, potassium, zinc, and magnesium was $68.4 \% \mathrm{w} / \mathrm{w}, 18.5 \% \mathrm{w} / \mathrm{w}$, and $13.1 \% \mathrm{w} / \mathrm{w}, 5.5 \% \mathrm{w} / \mathrm{w}$, $3.91 \mathrm{ppm}$, and 1,370 ppm respectively. This work aimed to determine the effect of molasses addition to the physio-chemical properties of multi-culture species of microalgae isolated from southern Java coastal region in Indonesia grown under mixotrophic culture. The cultivation in this work used medium which was selfformulated by the authors consisting of $\mathrm{NaNO}_{3}(5 \mathrm{~mL} / \mathrm{L}), \mathrm{H}_{3} \mathrm{BO}_{3}(1 \mathrm{~mL} / \mathrm{L})$, EDTA $(1 \mathrm{~mL} / \mathrm{L}), \mathrm{N}_{2} \mathrm{H}_{2} \mathrm{PO}_{4}(5$ $\mathrm{mL} / \mathrm{L}), \mathrm{FeSO}_{4}(1 \mathrm{~mL} / \mathrm{L}), \mathrm{MgSO}_{4}(1 \mathrm{~mL} / \mathrm{L}), \mathrm{NaCl}(1 \mathrm{~mL} / \mathrm{L})$, micronutrients $(1 \mathrm{~mL} / \mathrm{L})$, vitamin $\mathrm{B}_{1}(1 \mathrm{~mL} / \mathrm{L})$, and vitamin $\mathrm{B}_{12}(1 \mathrm{~mL} / \mathrm{L})$ in $500 \mathrm{~mL}$ of water. The medium will be treated to have molasses concentration of $0.05 \% \mathrm{v} / \mathrm{v}, 0.15 \% \mathrm{v} / \mathrm{v}, 0.25 \% \mathrm{v} / \mathrm{v}, 0.35 \% \mathrm{v} / \mathrm{v}$, and $0.45 \% \mathrm{v} / \mathrm{v}$.
\end{abstract}

\section{Introduction}

Many species of microalgae naturally has high nutrient content. To increase it, optimization could be made by modifying the growth determining factors such as nitrogen levels, light intensity, temperature, concentration of dissolved $\mathrm{CO}_{2}$, cultivation procedures, and salinity [1]. Environmental stress and limitations of nutrients (nitrogen for green microalgae and silica for diatoms) causes an accumulation of certain nutrient inside the cell. Under certain conditions, usually triggered by stress or atrophy, the nutrient content can be increased up to more than a half of the dry weight of the cell.

Current situation for efficient microalgae cultivation used mixotrophic system as the way. In the mixotrophic system, cell growth is not completely dependent on photosynthesis as the light energy is not the only factor restricting the growth. Both light and organic carbon substrate take part. The mixotrophic system allows the integration of both components of photosynthesis and heterotrophic during the diurnal cycle. This system will reduce the impact of shortage of biomass for dark respiration and lower the amount of organic substances which are used during cell growth [2].

To cultivate microalgae in the mixotrophic system, utilization of low cost carbon source from agroindustry waste which is molasses is studied. Previous study by O'Hara and Mundree [4], molasses possessed $\mathrm{pH}$ level of about 5 and contained carbon, nitrogen, inorganic salts such as $\mathrm{P}, \mathrm{Na}, \mathrm{K}, \mathrm{Ca}$, and other metals such as $\mathrm{Cu}, \mathrm{Zn}$, $\mathrm{Mn}, \mathrm{Fe}$, and $\mathrm{Mg}$ as well as vitamins [5]. All those minerals are necessary for better growth of microalgae. The other way to enhance the efficiency of microalgae cultivation is by using mixed culture grown microalgae [5]. Mixed culture condition enabled the self-defense of the microalgae species against "predators" like other microbes or bacteria. Therefore, this study aims to determine effect of molasses addition to the cell growth profile represented by cell amount and biomass dry weight and to the nutrients profile (lipid and chlorophyll)

\section{Methodology}

\subsection{Materials and apparatus}

Mixed cultures-grown microalgae were isolated from South Coast of Yogyakarta, Glagah, Indonesia. The growth medium used was supplied by Merck and using the formula shown by Table 1 and Table 2 [6] as well as molasses medium with the volume percentage of $0.05 \%$, $0.15 \%, 0.25 \%, 0.35 \%$, and $0.45 \%$

\footnotetext{
* Corresponding author: eko_suyono@ugm.ac.id
} 
Table 1. Growth medium formula of the macronutrients

\begin{tabular}{lcc}
\hline \multicolumn{1}{c}{ Component } & Stock Solution, g/L & $\begin{array}{c}\text { Amount taken from stock solution, mL stock } \\
\text { solution /L medium }\end{array}$ \\
\hline $\mathrm{NaNO}_{3}$ & \multicolumn{2}{c}{ Macronutrients } \\
$\mathrm{H}_{3} \mathrm{BO}_{3}$ & 250 & 5 \\
$\mathrm{EDTA}_{2} 2 \mathrm{Na}$ & 33.6 & 1 \\
$\mathrm{NaH}_{2} \mathrm{PO}_{4}$ & 45 & 1 \\
$\mathrm{FeSO}_{4}$ & 175 & 1 \\
$\mathrm{MgSO}_{4} .7 \mathrm{H}_{2} \mathrm{O}$ & 5 & 1 \\
$\mathrm{NaCl}$ & 50 & 1 \\
\hline
\end{tabular}

Table 2. Growth medium formula of the micronutrients and vitamins

\begin{tabular}{lcc}
\hline \multicolumn{1}{c}{ Component } & Stock Solution, g/L & $\begin{array}{c}\text { Amount taken from stock solution, } \mathrm{mL} \\
\text { stock solution /L medium }\end{array}$ \\
\hline & Micronutrients & \\
\hline $\mathrm{MnCl}_{4} 4 \mathrm{H}_{2} \mathrm{O}$ & 0.36 & 1 \\
$\mathrm{ZnSO}_{4}$ & 0.021 & 1 \\
$\mathrm{CoCl}_{2} \cdot 6 \mathrm{H}_{2} \mathrm{O}$ & 0.02 & 1 \\
$\left(\mathrm{NH}_{4}\right)_{2} \mathrm{Mo}_{7} \mathrm{O}_{24} .4 \mathrm{H}_{2} \mathrm{O}$ & 0.0093 & 1 \\
$\mathrm{CuSO}_{4} 5 \mathrm{H}_{2} \mathrm{O}$ & 0.02 & 1 \\
\hline & \multicolumn{1}{c}{ Vitamin } \\
\hline Vitamin B1 & $15.25 \mathrm{mg} / 100 \mathrm{~mL}$ & 1 \\
\hline Vitamin B2 & $12.5 \mathrm{mg} / 100 \mathrm{~mL}$ & \\
\hline
\end{tabular}

For analytical routines, there were ethanol $70 \%(\mathrm{CV}$. General Labora), chloroform (merck), methanol (Merck), distilled water, and acetone. In this study, the molasses was obtained from PT. Madu Baru, Bantul, D.I. Yogyakarta. The laboratory analysis from PT. Madu Baru gave composition of molasses as shown by Table 3 . The analysis of carbon source content was performed using an HPLC system (Knauer smart line RI detector 2300, Germany) with a column of Aminex HPX-87C 300 x 7.8 $\mathrm{mm}$ (Bio-Rad, USA) at $85^{\circ} \mathrm{C}$. Injection volume is $20 \mu \mathrm{L}$ and mobile phase was deionized water at flow rate of 0.6 $\mathrm{mL} / \mathrm{min}$. The analysis of element inside molasses was performed using Atomic Absorption Spectroscopy (AAS).

The experimental apparatus used in this study were spectrophotometer (Genesys 10 UV-VIS Thermoscientific), cuvette, micropipette, pipette tip, oven (ESCO Isoterm), analytical balance, $\mathrm{pH}$ meter, autoclave (ES-215 TOMY), digital lux meter LX-1010B, centrifuge (UNIVERSAL 320 R HettichC), microscope, optilab, and haemocytometer

\subsection{Cultivation Methods}

The molasses was diluted to eliminate water-insoluble material in accordance with the prescribed concentration. Liquid left for 24 hours in room temperature and then the supernatant is filtered with a $0.5-\mu \mathrm{m}$ filter paper and conditioned at a $\mathrm{pH}$ in accordance with the culture [7]. To prepare the growth medium, the chemicals were added to $1,000 \mathrm{~mL}$ of distilled water and were then homogenized. The $\mathrm{pH}$ level of the medium was set in between $7-8$. The growth medium was then sterilized by autoclaving for 15 minutes at the pressure of $15 \mathrm{psi}$ and temperature of $121^{\circ} \mathrm{C}$. Afterward, mixed-culture microalgae isolate of $250 \mathrm{~mL}$ were mixed in $250 \mathrm{~mL}$ growth medium with variation of volume percentage of molasses as many as $0.05 \%, 0.15 \%, 0.25 \%, 0.35 \%$, and $0.45 \%$. Cultures were incubated for 10 days with continuous aeration and lighting 
Table 3. Analysis of components inside molasses

\begin{tabular}{lrlc}
\hline \multicolumn{1}{c}{ Colasses } & \multicolumn{2}{c}{ Carbon Source inside Molasses } \\
\hline Carbon & \multicolumn{1}{c}{ Content } & Components & Content \\
Nitrogen & $61.44 \%$ & Sucrose & $68.4 \%$ \\
Phosphor & $6.02 \%$ & Glucose & $18.5 \%$ \\
Sodium & $0.29 \%$ & & \\
Potassium & $0.35 \%$ & Fructose & $13.1 \%$ \\
Calcium & $5.3 \%$ & & \\
Copper & $0.75 \%$ & Oxalic acid & \\
Zinc & $2.21 \mathrm{ppm}$ & \multirow{2}{*}{ Citric acid } & $3.22 \%$ \\
Manganese & $3.89 \mathrm{ppm}$ & & \\
Iron & $4.69 \mathrm{ppm}$ & & \\
Magnesium & $78.26 \mathrm{ppm}$ & & \\
\hline
\end{tabular}

\subsection{Parameters measurement}

Cell counting method follow Haemocytometer method as explained by [8]. Calculations done by counting the cells in the second chamber at the top and bottom Haemocytometer.

Productivity of the biomass is evaluated by measuring the biomass dry weight using gravimetric method by taking $5 \mathrm{~mL}$ sample and by filtering it with filter paper. Biomass was then wrapped in filter paper and put in the microwave for 15 minutes at $34^{\circ} \mathrm{C}$ until the constant weight was achieved.

Lipid data retrieval is conducted by following the method of Bligh and Dryer [9]. To measure the

$$
\begin{aligned}
& \text { number of cell } / \mathrm{mL}=\frac{\text { counted cell }}{5} \times \text { dillution factor } \times 25 \times 10^{4} \\
& \text { Chlorophyll A }(\mathrm{mg} / \mathrm{L})=11.75 \times(\text { Abs } 662)-2.35 \times(\text { Abs } 645) \\
& \text { Chlorophyll B }(\mathrm{mg} / \mathrm{L})=18.61 \times(\text { Abs } 645)-3.96 \times(\text { Abs } 662)
\end{aligned}
$$

chlorophyll content, microalgae samples as many as $5 \mathrm{~mL}$ was taken and put inside the tube. Afterward, it was centrifuged at rotational speed of 3,300 rpm for 15 minutes. The supernatant was taken and allowed to remain at the bottom of the tube and then $2 \mathrm{~mL}$ of acetone was added to be re-centrifuged at $1,800 \mathrm{rpm}$ for 10 minutes. Samples were transferred into a glass cuvette and placed in a spectrophotometer with absorbance at a wavelength of 645 and $662 \mathrm{~nm}$. Based on the absorbance of the spectrophotometer, the concentrations of chlorophyll A and B were calculated using the following equation [10]

\section{Results and Discussion}

Based on Fig. 1 (a), the lag phase occurs until day 1. At this phase, microalgae tried to adapt with the medium and prepare energy for cell division so that the growth rate was still very slow. From day 1 - day 8 , the $\log$ phase occurred. At this stage, there was an increase into very rapid growth rate of actively dividing cells of microalgae. After the $8^{\text {th }}$ day, the the phase of the microalgae growth seems to directly enter the death phase.

The highest density in the control was 2.4 million cells $/ \mathrm{mL}$ while on the molasses medium with $0.45 \%$ molasses achieved the highest density as many as 4.2 million cells $/ \mathrm{mL}$. This indicated that the content of molasses in the medium can increase the growth rate of microalgae. According to study by Kosakowska et al. [11], high concentrations of $\mathrm{Fe}^{2+}$ in the growth medium increased the absorption rate of nitrate and chlorophyll concentration during the cultivation period which led to the increasing of the rate of photosynthesis. The energy resulted from photosynthesis was used for growth. Iron deficiency can reduce the efficiency of photosynthesis of microalgae.

From Table 3, it was shown that molasses also contained high magnesium content. Magnesium was the main cation cell and the base material of chlorophyll. Primary cation cell and inorganic cofactor were useful for many enzymatic reactions functioning in the unification of the substrate and enzyme. Magnesium was also an activator for ribulosebisphosphate carboxylase and phosphoenolpyruvate carboxylase which were two essential enzymes in carbon fixation during photosynthesis. Therefore, the higher the magnesium contents in the medium, the more active the photosynthesis activity in the cell.

Sucrose is also instrumental in the microalgae growth by participating in the metabolic processes. In addition to cell division, a carbon source in the form of sucrose is also used for cell expansion. The more nutrients are available, the more the cellulose produced as primary metabolites. The cellulose binds to form solid and compact bonding. At the moment of microalgae cells were dried in the oven, the measured dry weight was the cell wall. In the bulk of 
the cell wall, cellulose was the major composing component.

Fig. 1 (b) showed that the highest dry weight of biomass in control was $1.35 \mathrm{mg} / \mathrm{mL}$ while on the treatment with the molasses addition to the growth medium with molasses concentration of $0.45 \%$ gave the highest dry weight as many as $1.46 \mathrm{mg} / \mathrm{mL}$. Fig. 2 showed that the dry weight per cell density increased along the time. This occurred because the nutrients contained in the molasses tend to be used for growth activity than for the formation of cell walls.

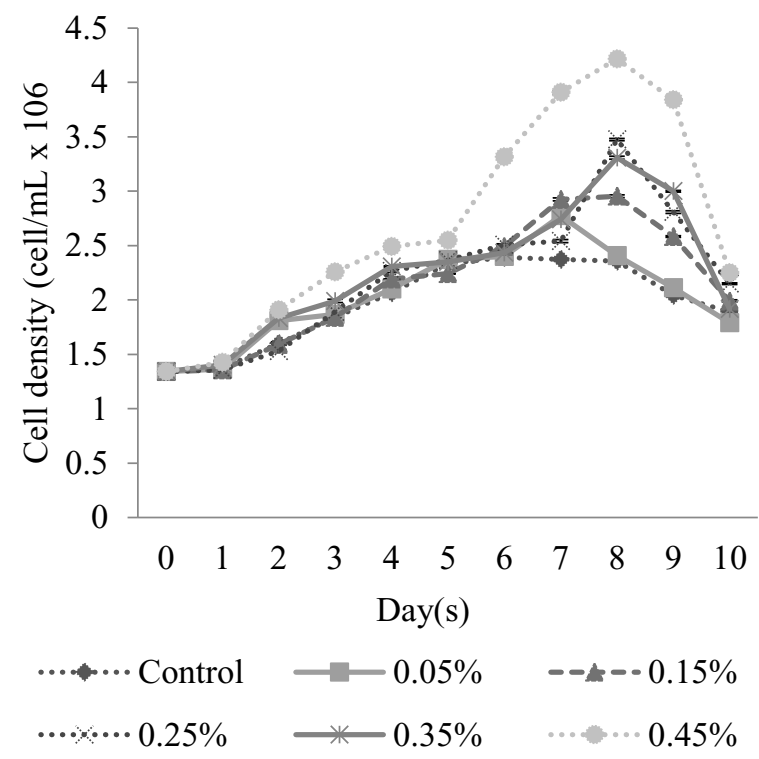

(a)

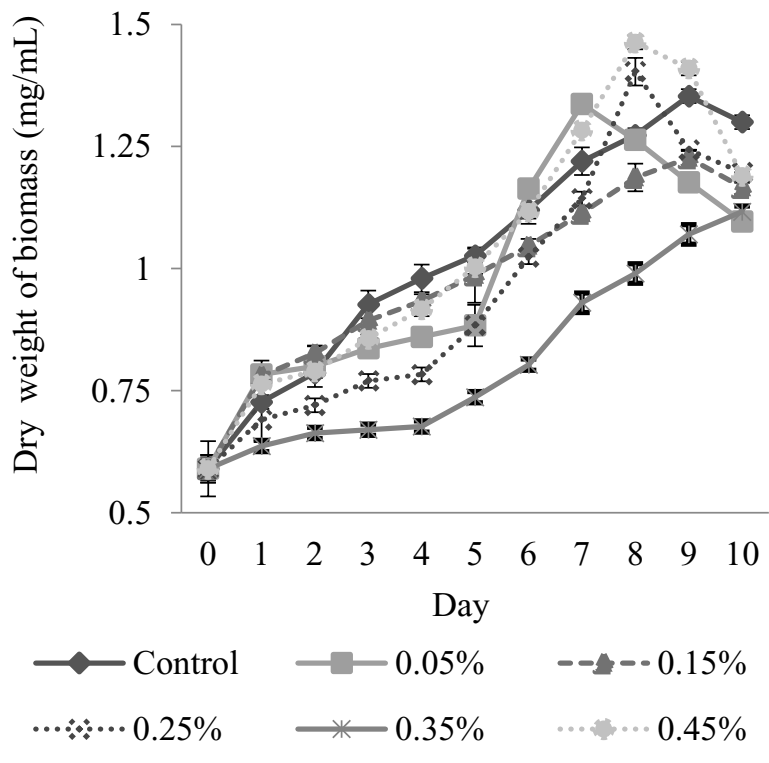

(b)

Fig. 1. (a) The cell density profile versus time (b) Dry weight of microalgae biomass profile versus time during the cultivation of microalgae consortium of Glagah isolate

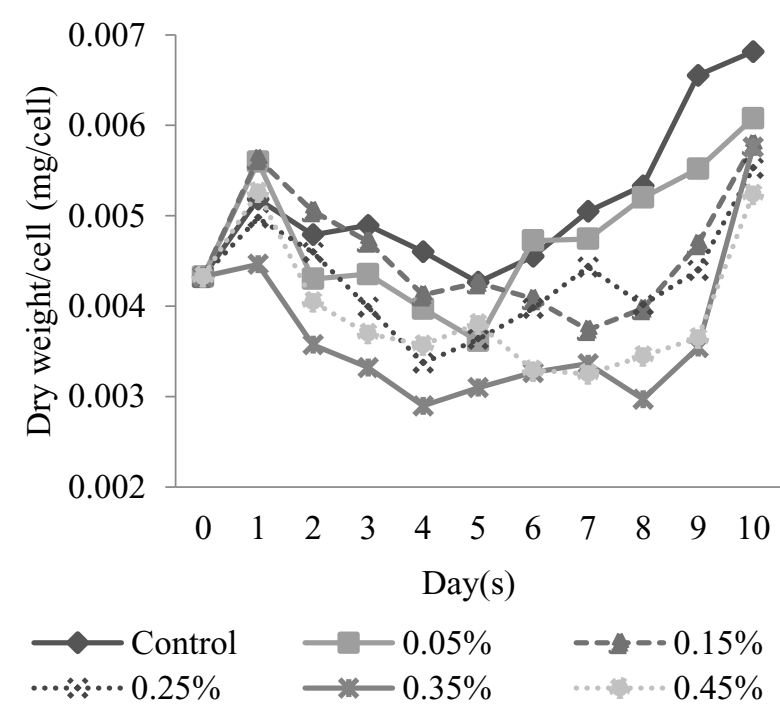

Fig. 2. Profile of biomass dry weight/cell density of microalgae consortium of Glagah isolates

Fig.s 3 showed that the highest content of chlorophyll A was in the medium with molasses concentration of $0.25 \%$ reaching up to $1,794 \mathrm{mg} / \mathrm{mL}$, much higher than the control (only $1,287 \mathrm{mg} / \mathrm{mL}$ ). On the other hand, the content of chlorophyll B in medium with $0.25 \%, 0.35 \%$, $0.45 \%$ molasses concentration were relatively the same but were still much higher than the control chlorophyll B production.

On the first day, microalgae were still in the lag phase where they adapt with the new conditions so that the chlorophyll content increased slightly. On day 2-7, the chlorophyll content increased significantly because microalgae had adapted with the new environment and begin to increase their metabolic activities. As the consequence of the abundant availability of sufficient nutrients, the growth of microalgae and chlorophyll synthesis became faster. On day 8 , chlorophyll content in microalgae started to decline because the nutrient content in the medium started running out $[12,13]$.

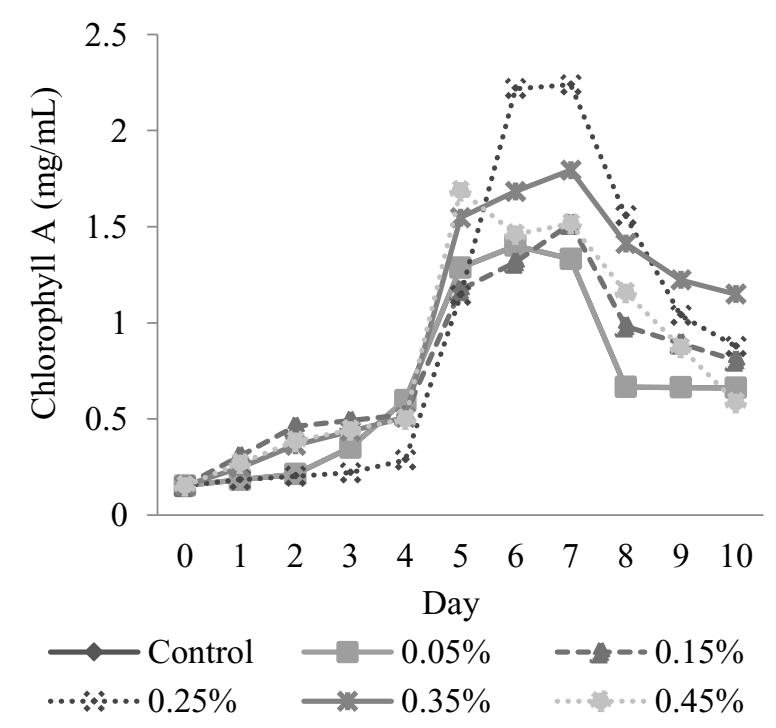

(a) 


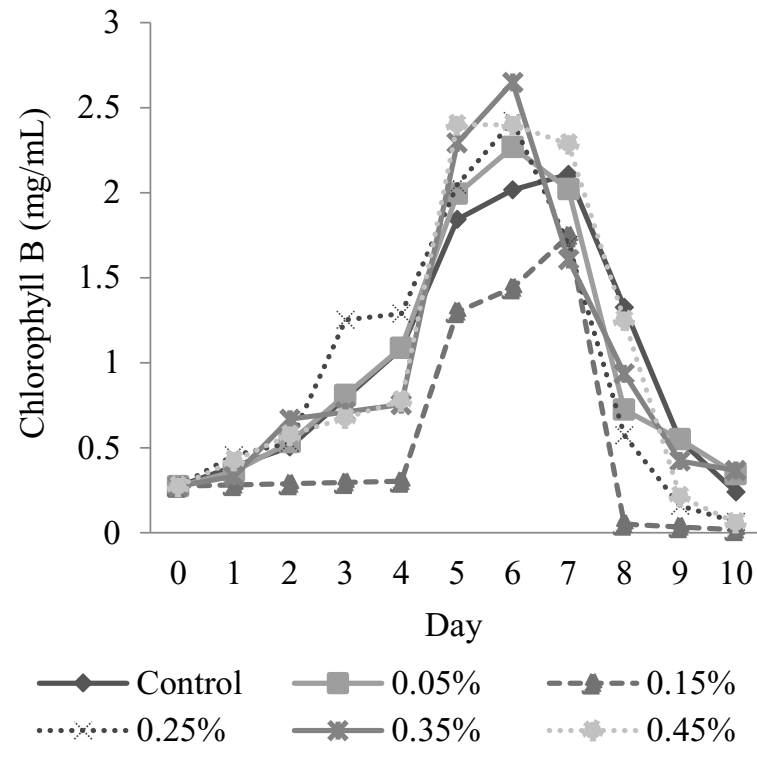

(b)

Fig. 3. Profile of (a) Chlorophyll A and (b) Chlorophyll B content

Chlorophyll content in molasses medium was higher than the control because of the magnesium contained in the molasses. According to Chen and Shetty [14], magnesium functioned as the unification of the substrate and enzyme through many enzymatic reactions. It is important for reactions involving ATP because magnesium served to connect the ATP molecule to the active site of the enzyme. The more magnesium content in the medium, the higher the rate of photosynthesis in the cells was. Magnesium also acts as an activator for ribulosebisphosphate carboxylase and phosphoenolpyruvate carboxylase [2], two essential enzymes in carbon fixation during photosynthesis. Magnesium contained in the addition of molasses will stimulate metabolic activity, so that microalgae can grow better and produce more chlorophyll [13].

In Fig. 4, the comparison between chlorophyll $\mathrm{A}$ and $\mathrm{B}$ show the positive trend on daily basis for 10 days of cultivation. This phenomenon showed that the molasses addition made microalgae adapted through capturing more lights since the main function in capturing light for photosynthesis was performed by chlorophyll A, while chlorophyll $\mathrm{B}$ functioned to extend the range of wavelengths capture capability of chlorophyll A.

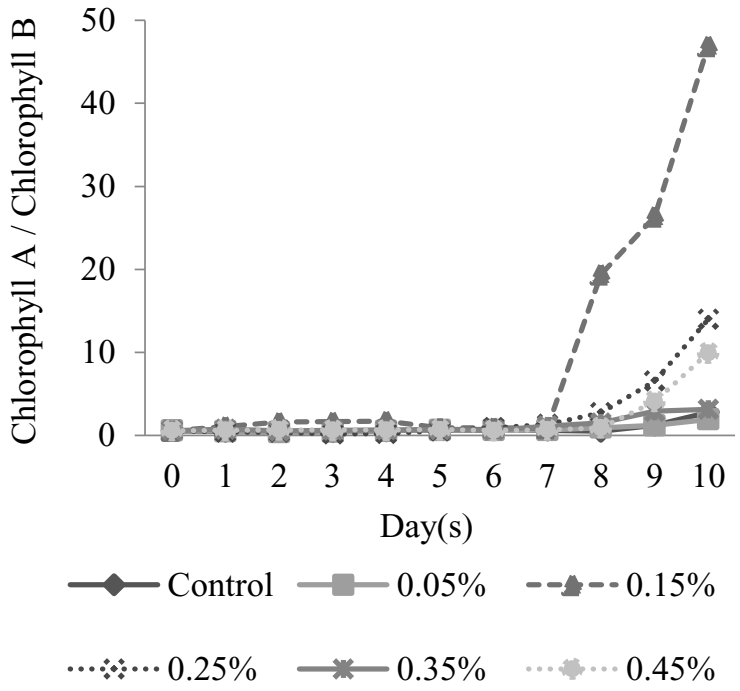

Fig. 4. Chlorophyll A/B profile of cultivation with and without molasses addition

In Fig. 3 and Fig. 5, on day 8, lipid content increased significantly as the chlorophyll content in microalgae decreased. The decrease in chlorophyll content was stress expression of microalgae due to lack of nitrogen supply after several days of cultivation so that the remaining carbon source was converted into lipids for their survival.

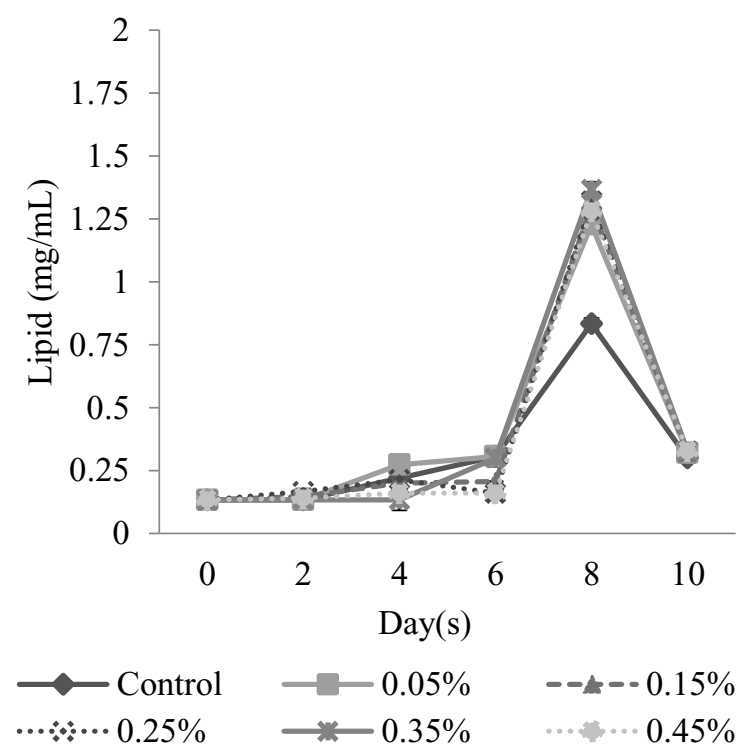

(a) 


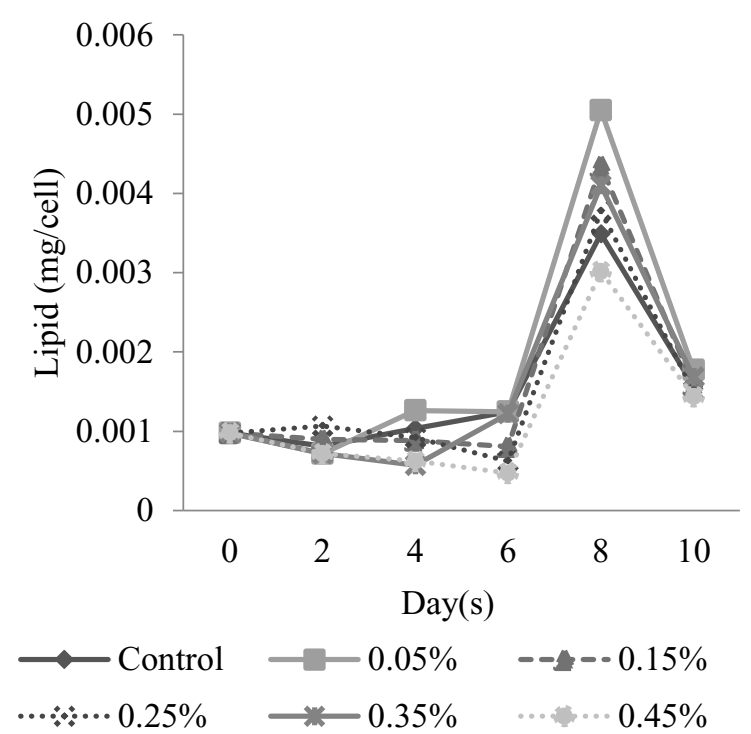

(b)

Fig. 5. Profile of a). lipid content of microalgae consortium of Glagah isolate b). lipid/cell density profile after 10 days of microalgae cultivation

\section{Conclusions}

The addition of molasses to the growth medium of microalgae had positive impact due to better nutrient content inside the microalgae. However, in the case of increasing the chlorophyll A content in microalgae, there was optimum concentration of molasses (asymptote point) which was $0.25 \%$. Meanwhile, for the other parameters, the higher the molasses concentration, the better the nutrients content in the microalgae.

The authors are grateful for the financial support from Indonesian General Directorate of Higher Education (DIKTI) in the form of PUPT research grant.

\section{References}

1. H. Sudibyo, Y.S. Pradana, T.T. Samudra, A. Budiman, Indarto, E.A. Suyono, Energy Procedia, Study of cultivation under different colors of light and growth kinetic study of Chlorella zofingiensis Dönz for biofuel production, 105, 270-276, 2017.

2. A. Karemore, R. Pal, R. Sen, Algal Res., Strategic enhancement of algal biomass and lipid in Chlorococcum infusionum as bioenergy feedstock, $\mathbf{2}$, 113-121, 2013

3. I. O'Hara, S. Mundree, Sugarcane-based Biofuels and Bioproducts. pp. 117-119, New York, USA: John Wiley \& Sons, 2016.

4. N.S. El-Gendy, H.R. Madian, S.S. Abu, Int. J. Microbiol., Design and Optimization of a Process for Sugarcane Molasses Fermentation by Saccharomyces cerevisiae Using Response Surface Methodology, 18, 2, 2013.
5. Y.S. Pradana, H. Sudibyo, E.A. Suyono, A. Budiman, Energy Procedia, Oil Algae Extraction of Selected Microalgae Species Grown in Monoculture and Mixed Cultures for Biodiesel Production, 105, 277 282, 2017.

6. E.A. Suyono, M. Nuhamunada, N. Ramadhani, Ramdhaniyah, Asian Jr. of Microbiol. Biotech. Env. Sc., Lipid Content from Monoculture of Micro Algae Chlorella zofingiensis Dönz and mixed culture of Glagah isolate in laboratory scale and raceway pond for biodiesel production, 18 (1), 95-100, 2016.

7. Y. Goksungur, F. Mantzouridou, T. Roukas, J. Chem. Technol. Biotechnol., Optimization of the production of $\beta$-carotene from molasses by Blakeslea trispora: a statistical approach, 77, 933-943, 2002.

8. N.A. Punchard, Haemocytometer Instruction Sheet (for improved Neubauer Haemocytometer), London, UK: University of East London, 2001.

9. Y. Han, Q. Wen, Z. Chen, P. Li, Energy Procedia, Review of Methods Used for Microalgal LipidContent Analysis, 12, 944-950, 2011.

10. S. Dere, T. Gunes, R. Sivaci, Turk. J. Bot., Spectrophotometric Determination of Chlorophyll A, B and Total Carotenoid Contents of Some Algae Species Using Different Solvents, 22 (1), 13-17, 1998

11. A. Kosakowska, J. Lewandowska, J. Ston, K. Burkiewicz, Biometals, Qualitative and quantitative composition of pigments in Phaeodactylum tricornutum (Bacillariophyceae) stressed by iron, 17, 45-52, 2004.

12. A.G. Moat, J.W. Foster, M.P. Spector, Microbial Physiology $4^{\text {th }} e d$. New York, USA: John Wiley and Sons Inc., 2002.

13. L. Taiz, E. Zeiger, Plant Physiology $3^{\text {th }}$ ed. Sunderland, England: Sinauer Associates, 2002.

14. J. Chen, H.P.C. Shetty, Culture of Marine Feed Organisms, p. 38, Bangkok, Thailand: National Inland Institute Kasetsart University Campus, 1991 